\title{
MINERALOGICAL AND GEOCHEMICAL COMPOSITIONS OF MODERN BIVALVE SHELLS FROM THE MEDITERRANEAN COAST OF EGYPT
}

By

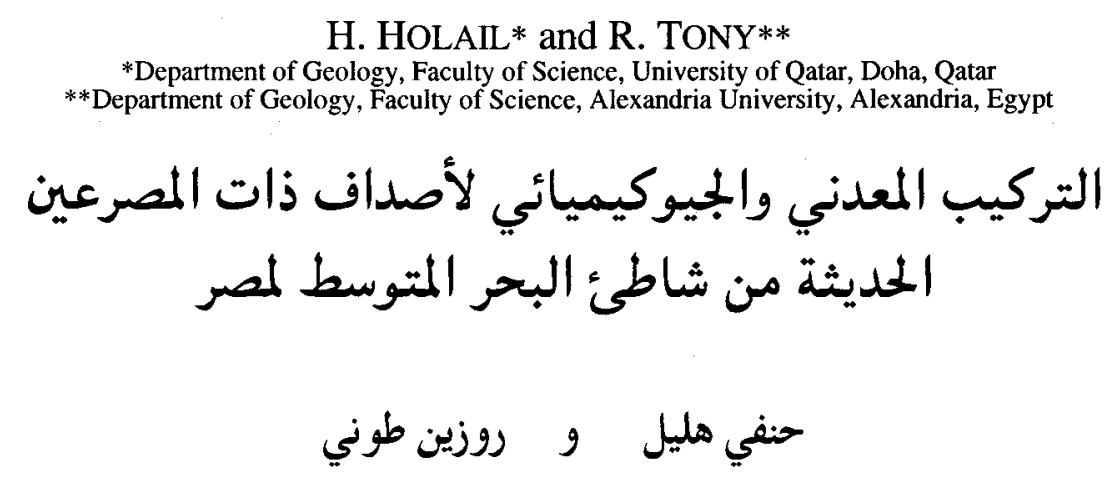

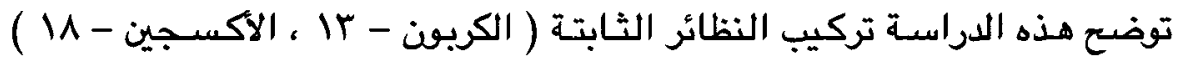

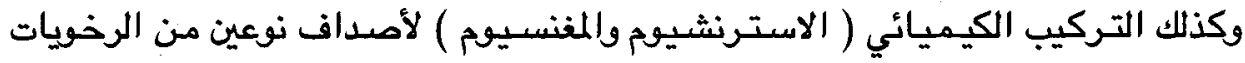

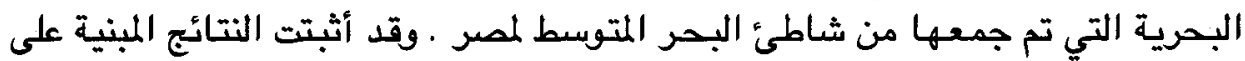

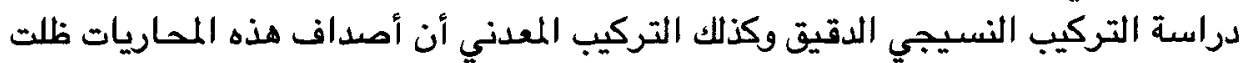

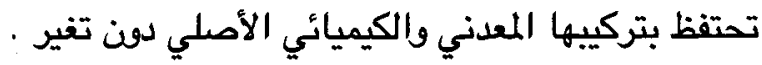

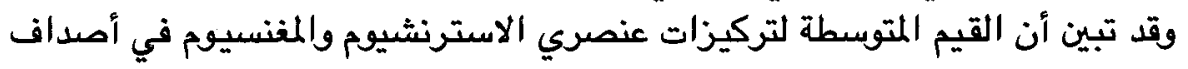

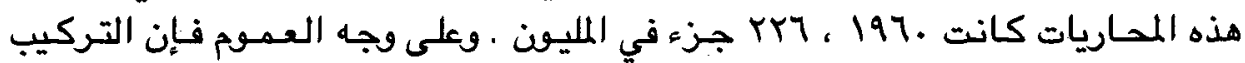

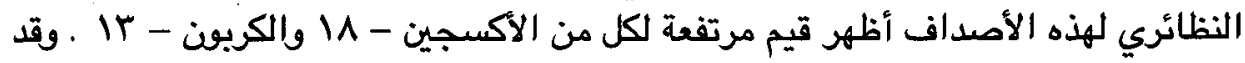

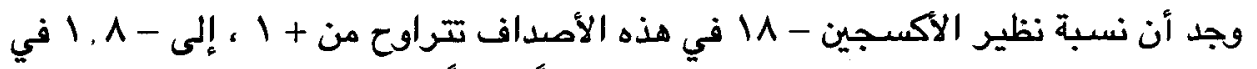

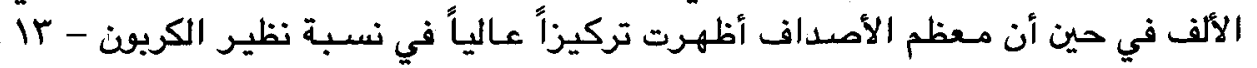

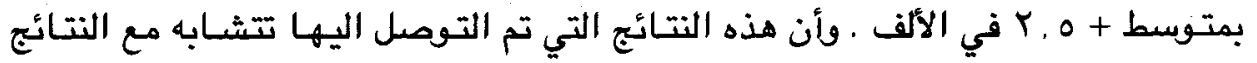

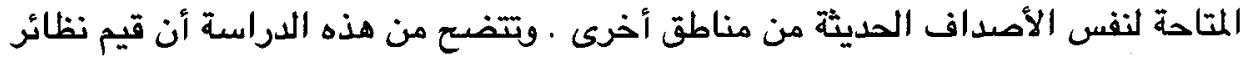

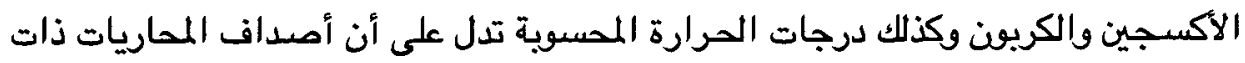

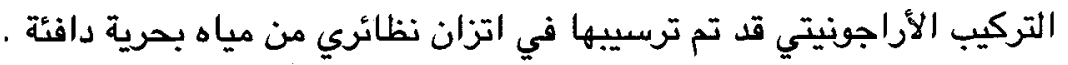

Key Words: Stable isotopes, Egypt, Mediterranean, Bivalve, Temperature, Biological fractionation, Aragonite

\section{ABSTRACT}

The stable isotopic $\left(\delta^{13} \mathrm{C}\right.$ and $\delta^{18} \mathrm{O}$ ) and elemental ( $\mathrm{Sr}$ and $\mathrm{Mg}$ ) compositions are presented for marine mollusc Carditacea and Solenacea shells collected off the Mediterranean coast of Egypt. Based on shell microstructures and mineralogy, the bivalve shells are preserved in their original mineralogy and chemistry.

The $\mathrm{Sr}$ and $\mathrm{Mg}$ concentrations of the bivalve shells have mean values of $1960 \mathrm{ppm}$ and $226 \mathrm{ppm}$; respectively. The stable isotopic composition generally show high values of $\delta^{18} \mathrm{O}$ and $\delta^{13} \mathrm{C}$. The $\delta^{18} \mathrm{O}$ values range from +0.1 to $-1.8 \%$ PDB and most shells are highly enriched in ${ }^{13} \mathrm{C}$; averaging $+2.5 \%$ o PDB. These elemental and isotopic signatures are similar to those of modern marine bivalves from other localities. The oxygen and carbon isotopic compositions, together with the calculated temperatures, suggest that the aragonitic bivalve shells were precipitated in isotopic equilibrium from warm marine waters.

\section{INTRODUCTION}

Numerous studies have examined the relationship between the trace element contents of mollusc shells and environmental conditions (Allen, 1960; Jones. 1985; Al-Aasm and Veizer;
1986; Morrison and Brand, 1986; Wassenaar et al., 1988; Barbin et al.; 1991). The uptake of trace elements into marine mollusc shells is dependent upon the mineralogy of the skeleton, salinity, temperature and concentrations of these elements in the seawater. In addition, the biochemistry of 
molluses can be further complicated by the organisms themselves exerting a biological control. This process of biological fractionation can lead to an enrichment or depletion of a specific trace element in the shell-carbonate of marine molluscs (Lowenstam, 1961; Harris, 1965).

Most molluscs precipitate their shells in isotopic equilibrium with the ambient seawater and exert only a minimal vital effect over their isotopic composition (Rye and Sommer, 1980; Muhs and Kyser, 1987). Thus, unaltered molluscs shells record the oxygen isotopic ratios of the bodies of water in which they grew. In addition, water temperature, salinity and the total dissolved carbon content have been recognized as major factors in controlling the oxygen and carbon isotopic compositions in the shell-carbonate of marine molluscs. These factors, along with vital effects, represents the most significant problems to direct environmental interpretation of isotopic compositions of marine mollusc shells.

The sediments which yielded and are associated with these shells are postulated to have been deposited within marine settings (Holail and Rashed, 1992). Salinity is about 39.2\%o and not significantly different from one site to another. Water temperatures varying from 17 to $26.5{ }^{\circ} \mathrm{C}$. Temperature seasonality or the difference between winter and summer temperatures at any given sites within the study area is generally between 8 and $10^{\circ} \mathrm{C}$.

The aim of this paper is to evaluate the mineralogical and chemical compositions of modern bivalve molluscs collected off the Mediterranean coast of Egypt. Specific emphasis is placed on the oxygen isotope thermometry in the light of isotopic compositions of the unaltered shells. The results are interpreted with regard to physio-chemical conditions of the Mediterranean seawater.

\section{MATERIAL AND METHODS}

A total of 100 bivalve mollusc shells, representing two superfamilies, were utilized for this study. The studied superfamilies were: Carditacea and Solenacea. They were collected and separated from the exposed modern beachrocks off the Mediterranean coast of Egypt (Fig. 1). In these rocks, mollusc-bivalves and gastropods are the most abundant shells, whereas corals and intraclasts occur in minor quantities.

All shells were first examined under a binocular microscope. Fracture surfaces of 10 shell fragments were evaluated for microstructure and shell components using the scanning electron microscope. Mineralogy of the shell components was examined by $\mathrm{X}$-ray diffraction with $\mathrm{Cu}-\alpha$ radiation and $\mathrm{Ni}$-filter. The percentages of aragonite in the shells were calculated following the method described in Milliman (1974). Thirty shell samples were powdered and analyzed for $\mathrm{Mg}$ and $\mathrm{Sr}$ on an atomic absorption spectrophotometer.

For isotopic studies, thirty powdered shell samples were reacted in $\mathrm{H}_{3} \mathrm{PO}_{4}$ at $50^{\circ} \mathrm{C}$ in vacuo. The evolved $\mathrm{CO}_{2}$ gas was analyzed for oxygen and carbon isotopes on a VG 602D mass spectrometer at the University of Michigan, Stable Isotope Laboratory, (U.S.A.). All data were corrected for ${ }^{17} \mathrm{O}$ following the procedure of Craig (1957). Oxygen and carbon isotopic data were expressed in the usual $\delta$-notation and given in permil relative to PDB standard. Analytic calibration was monitored through daily bracketing of unknowns by NBS-20, and mean results for standards diverged from reported values by less than $0.02 \%$ for carbon and oxygen. Sample analytic precision was $0.02 \%$ for $\delta^{13} \mathrm{C}$ and $0.01 \%$ for $\delta 18 \mathrm{O}$.

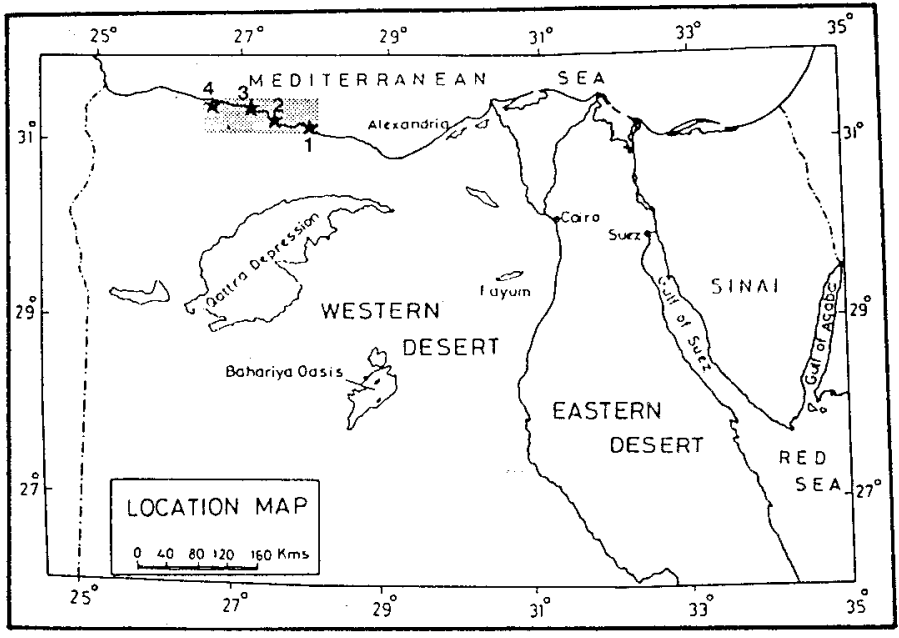

Fig. 1: Location map of Egypt, showing sites where marine bivalve shells were collected.

\section{RESULTS AND DISCUSSION}

\section{Microstructure and Mineralogy of Bivalve Shells}

The studied mollusc-bivalve shells are belonging to two superfamilies, the Carditacea and the Solenacea. The Carditacea are generally small and thick shelled. The valves are inequilateral, cordiform in shape or trigonal, trapezoidal and occasionally mytiliform. The shell color is whitish with a rose tint.

The Solenacea: members of this group are generally elongated shells, laterally compressed, gaping anteriorly and posteriorly; the shell is fragile and smooth. The ligament is external; the dentition consists of one or two cardinals on each valve; lateral are absent. The pallial sinus is generally small, but in some forms like Solen, it may be large. The Solenacea are the fastest burrowers in inshore fine sands.

Petrographic and SEM studies of these bivalve shells revealed the existence of two microstructure types. The shells are composed of two layers. The outer layer of many shells is relatively thick and composed of a crossed-lamellar microstructure (Fig. 2). The inner layer is of the complex-crossed-lamellar microstructure. The crossed-lamellar microstructure consists of elongate, interdigitating sheets oriented with the major and minor axes in the plane of the shell surface. These sheets are called the first order lamellae, which are built of inclined second-order lamels, which in turn built-up of fine third-order lamellae. The first-order lamels are transected at a very shallow angle relative to their length. The smaller second-order lamellae appear to cross at angles of $70^{\circ}$ and $110^{\circ}$ (Fig. 2). The complex-crossed-lamellar microstructure consists of a complicated arrangement of units of opposed second order lamels of the type present in crossed-lamellar structure. 


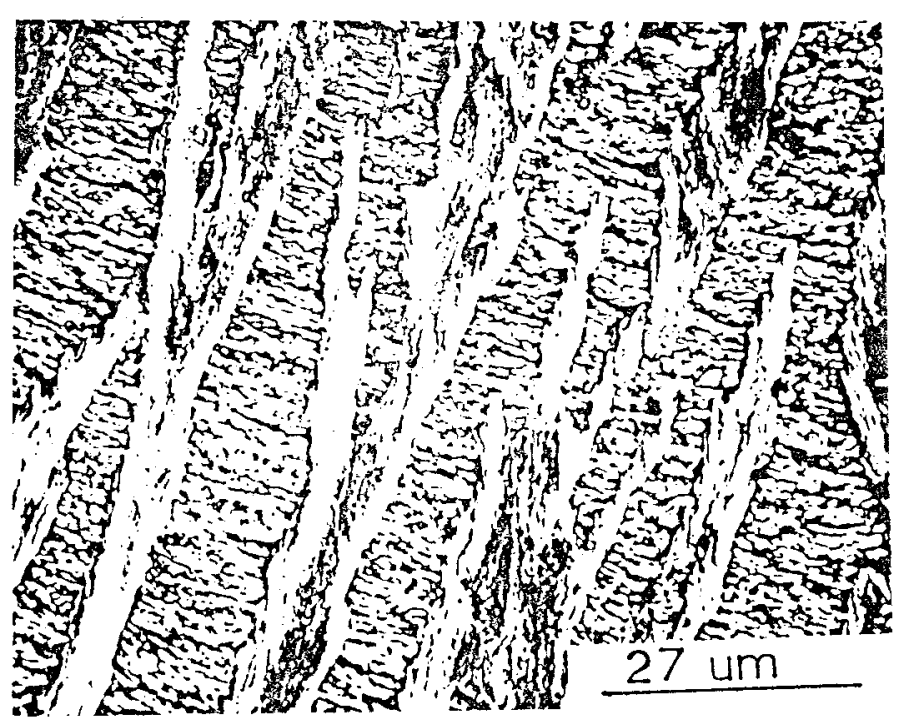

Fig. 2: Scanning electron photomicrographs of marine bivalve shells, showing crossed-lamellar microstructure (aragonite).

Structure of shells layers are useful in selecting the best-preserved fossil material, because corresponding structure can be recognized in extent unaltered bivalve, and some of them are mineralogy specific (Bathurst, 1975). In this study, aragonite bivalve shells (Fig. 3) show crossed-lamellar in their shell layers. These shells are therefore likely to have retained their record of the original trace elements and oxygen and carbon isotopic compositions.

\section{Trace elements}

The Sr concentrations of the studied bivalve shells range from 1040 to $2600 \mathrm{ppm}$ with a mean of $1960 \mathrm{ppm}$, whereas the $\mathrm{Mg}$ concentrations range from 120 to $370 \mathrm{ppm}$ with a mean of $226 \mathrm{ppm}$ (Table 1). These values are within the range of molluscan levels of $\mathrm{Sr}$ at $1100-4000 \mathrm{ppm}$ (Lowenstam, 1963; Friedman, 1968) and $\mathrm{Mg}$ at 5-1300 ppm (Morrison and Brand, 1986). However, the observed concentrations of the $\mathrm{Sr}$ and $\mathrm{Mg}$ are less than concentrations encountered in aragonite precipitated as cement and non-skeletal grain in modern seas which commonly fall within the average of $9720 \mathrm{ppm} \mathrm{Sr}$ and 1760 ppm Mg (Brand and Veizer, 1983).

Table 1

Chemical compositions of the studied bivalve shells

\begin{tabular}{|c|c|c|c|c|c|}
\hline & & $\mathrm{Mg} \mathrm{ppm}$ & Sr ppm & $\delta^{180 \%} \mathrm{PDB}$ & $\delta^{13} \mathrm{C} \%$ PDB \\
\hline \multicolumn{6}{|c|}{ Carditacea } \\
\hline \multirow[t]{4}{*}{ Site 1} & 1 & 220 & 1640 & -0.7 & 3.2 \\
\hline & 2 & 260 & 1710 & -0.8 & 2.1 \\
\hline & 3 & 210 & 2420 & +0.1 & 3.8 \\
\hline & 4 & 250 & 2120 & -0.4 & 2.3 \\
\hline \multirow{4}{*}{ Site 2} & 5 & 220 & 2280 & -0.3 & 1.4 \\
\hline & 6 & 270 & 180 & -0.1 & 3.1 \\
\hline & 7 & 190 & 1670 & -1.2 & 2.9 \\
\hline & 8 & 330 & 2320 & -0.7 & 3.6 \\
\hline \multirow{4}{*}{ Site 3} & 9 & 150 & 2410 & -0.5 & 1.6 \\
\hline & 10 & 140 & 1980 & -0.4 & 4.0 \\
\hline & 11 & 180 & 1680 & -1.3 & 3.2 \\
\hline & 12 & 210 & 2280 & -1.5 & 2.0 \\
\hline \multirow[t]{3}{*}{ Site 4} & 13 & 310 & 2600 & -1.4 & 2.3 \\
\hline & 14 & 280 & 2150 & -1.8 & 1.8 \\
\hline & 15 & 230 & 1860 & -0.3 & 1.6 \\
\hline \multicolumn{2}{|l|}{ MEAN } & 230 & 2061 & -0.8 & 2.4 \\
\hline
\end{tabular}

Solenacea
Table 1 Contd.

\begin{tabular}{|c|c|c|c|c|c|}
\hline & & $\mathrm{Mg} \mathrm{ppm}$ & Sr ppm & $\delta^{18} \mathrm{O} \%_{c} \mathrm{PDB}$ & $\delta^{13} \mathrm{C} \%$ PDB \\
\hline \multirow[t]{4}{*}{ Site 1} & 16 & 140 & 1780 & $\begin{array}{l}-0.8 \\
\end{array}$ & 2.0 \\
\hline & 17 & 350 & 2510 & -1.0 & 3.2 \\
\hline & 18 & 370 & 2180 & -0.5 & 2.7 \\
\hline & 19 & 180 & 2010 & -1.1 & 1.4 \\
\hline \multirow[t]{4}{*}{ Site 2} & 20 & 120 & 1370 & -0.2 & 2.9 \\
\hline & 21 & 230 & 2340 & $=0.9$ & 3.5 \\
\hline & 22 & 160 & 2210 & -1.3 & 4.0 \\
\hline & 23 & 160 & 1640 & -1.1 & 1.5 \\
\hline \multirow[t]{4}{*}{ Site 3} & 24 & 140 & 1380 & -1.2 & 2.8 \\
\hline & 25 & 310 & 1490 & -0.6 & 3.6 \\
\hline & 26 & 360 & 1960 & -1.2 & 3.1 \\
\hline & 27 & 150 & 1040 & -0.4 & 2.4 \\
\hline \multirow[t]{3}{*}{ Site 4} & 28 & 180 & 2250 & -0.3 & 2.1 \\
\hline & 29 & 230 & 1810 & -0.7 & 1.9 \\
\hline & 30 & 250 & 1980 & -0.8 & 1.6 \\
\hline MEAN & & 222 & 1863 & -0.8 & 2.6 \\
\hline
\end{tabular}

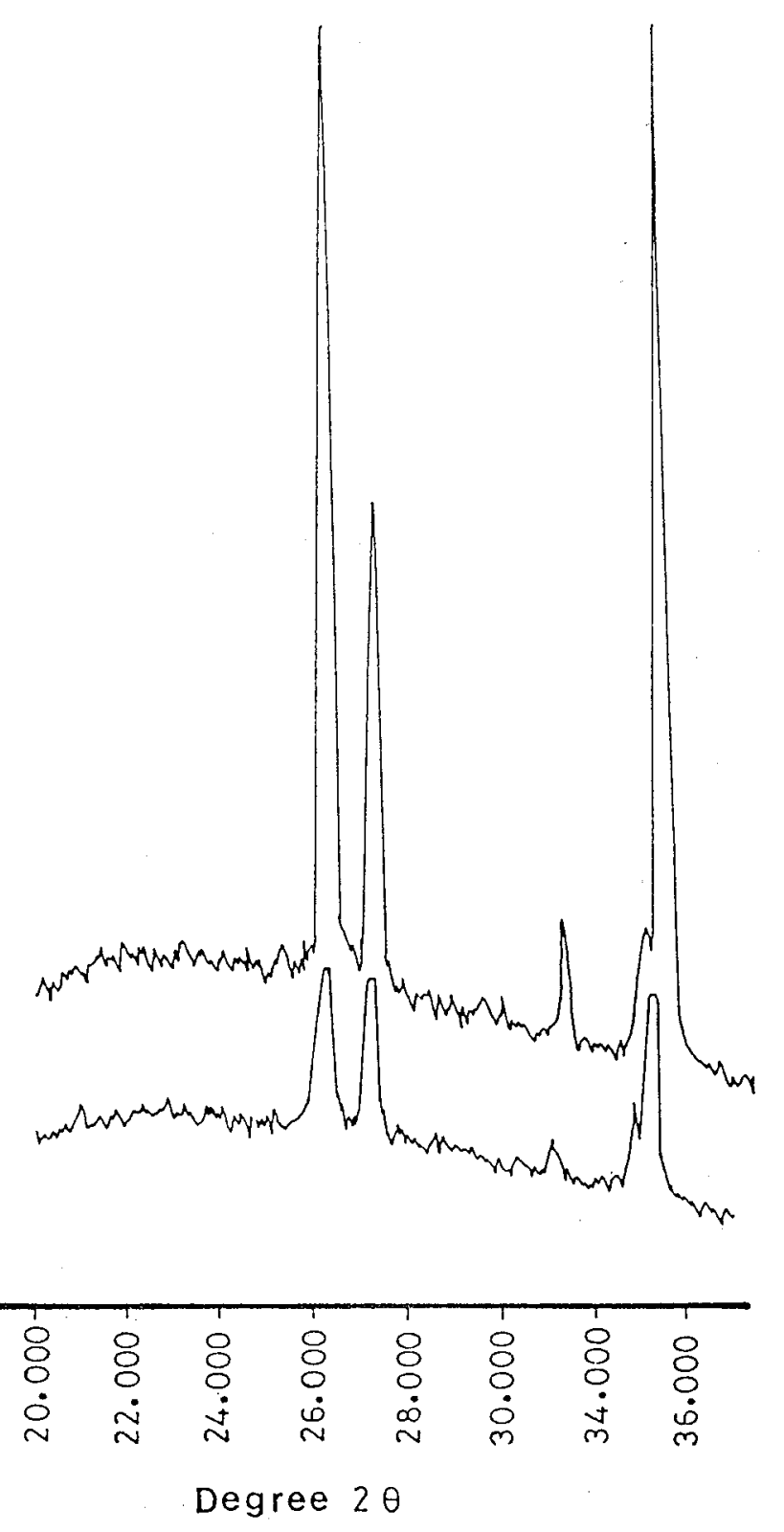

Fig. 3: X-ray diffractogram of powdered bivalve shells. All peaks can be assigned to aragonite reflections. 
$\mathrm{Sr}$ and $\mathrm{Mg}$ incorporation in carbonate minerals are controlled by the distribution coefficient $\mathrm{D}$, as outlined by Kinsman $\left(1969\right.$, where $m_{M e}$ and $m_{C a}$ represent molar concentrations of the trace element and molar concentrations of $\mathrm{Ca}$ in the fluid and solid phases.

$$
\left(\mathrm{m}_{\mathrm{Me}} / \mathrm{m}_{\mathrm{Ca}}\right)_{\text {solid }}=\mathrm{D}\left(\mathrm{m}_{\mathrm{Me}} / \mathrm{m}_{\mathrm{Ca}}\right)_{\mathrm{fluid}}
$$

The distribution coefficient of $\mathrm{Sr}$ in aragonite is 0.9-0.2 (Kinsman and Holland, 1969). Mg distribution coefficient is about 0.0006-0.005 (Brand and Veizer, 1980). These values of the distribution coefficient are dependent on temperature, salinity and chemical compositions of the fluid and solid phases. In addition, the biogeochemistry of invertebrate skeletons can be further complicated by the organisms themselves exerting a biological control. This process of biological fractionation can lead to an enrichments or depletion of a specific trace element in the shell carbonates. Molluscs that precipitate aragonite shells discriminate against incorporation of $\mathrm{Sr}$ (Lowenstam, 1961; Veizer, 1983).

Correlation analysis has been conducted to assess the covariation of $\mathrm{Sr}$ and $\mathrm{Mg}$ contents as dependent variables in the aragonite bivalve shells. The correlation shows no significant trend (Fig. 4). Furthermore, there are no significant differences in the Sr and $\mathrm{Mg}$ contents of the bivalve shells from the various studied sites. This is not unusual since the $\mathrm{Sr}$ and $\mathrm{Mg}$ content of molluscan pallial fluids are commonly controlled physiologically (Bathurst, 1975). Therefore, the Sr and $\mathrm{Mg}$ contents are reasonable for the studied shells.

\section{Carbon and oxygen isotopes}

Stable ${ }^{13} \mathrm{C}$ and $18 \mathrm{O}$ isotope data (Table 1), plotted versus $\mathrm{PDB}$, are illustrated on a carbon versus oxygen isotope cross-plot (Fig. 5). The isotopic composition of the studied bivalve shells falls within a distinct isotopic field (Fig. 6). These results are interpreted as original isotopic signatures that have experienced no diagenetic trend. This interpretation is based on 1) the well-preserved depositional microstructures and mineral composition of the bivalve shells, and 2) the trace element $(\mathrm{Sr}$ and $\mathrm{Mg}$ ) and isotopic values.

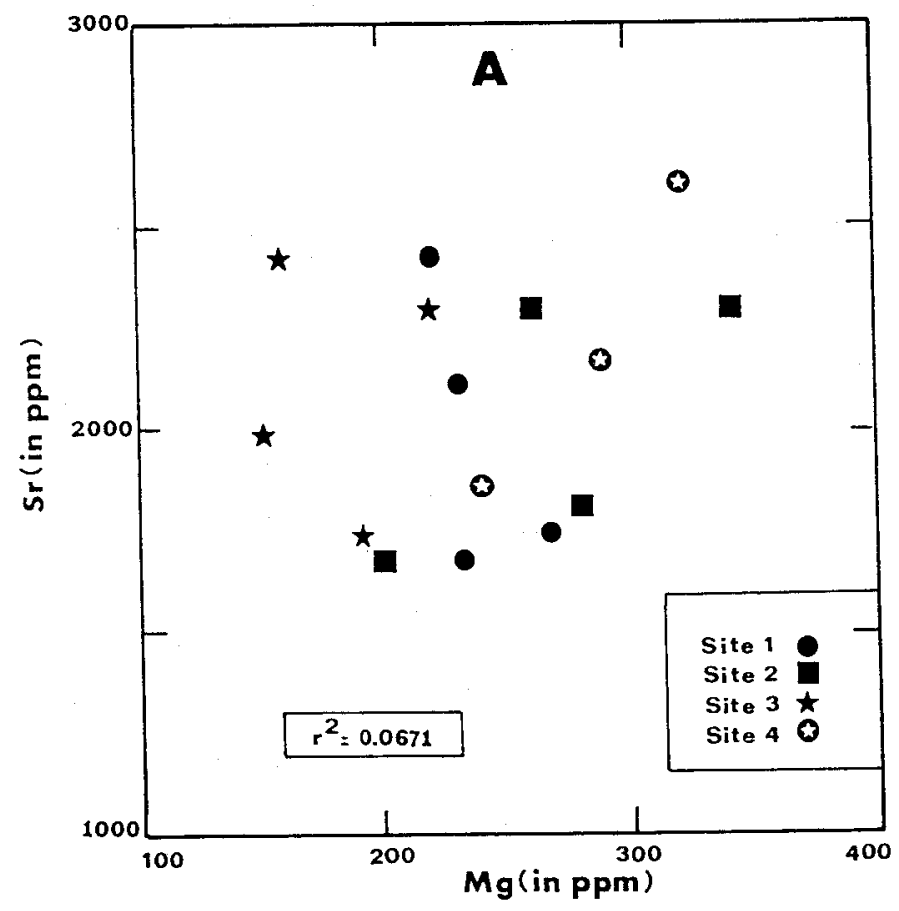

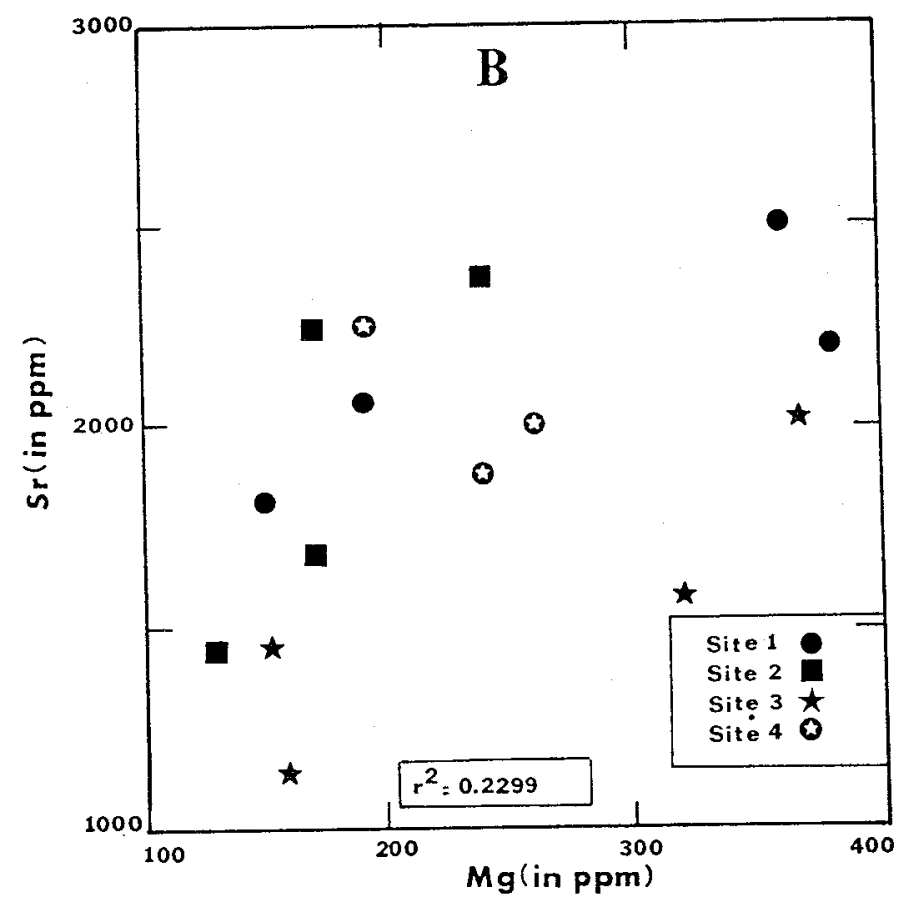

Fig. 4: Magnesium and strontium concentrations of bivalve shells. A- Carditacea. B- Solenacea.

\section{Carbon and oxygen isotopes}

Stable ${ }^{13} \mathrm{C}$ and ${ }^{18} \mathrm{O}$ isotope data (Table 1), plotted versus $\mathrm{PDB}$, are illustrated on a carbon versus oxygen isotope cross-plot (Fig. 5). The isotopic composition of the studied bivalve shells falls within a distinct isotopic field (Fig. 6). These results are interpreted as original isotopic signatures that have experienced no diagenetic trend. This interpretation is based on 1) the well-preserved depositional microstructures and mineral composition of the bivalve shells, and 2) the trace element $(\mathrm{Sr}$ and $\mathrm{Mg}$ ) and isotopic values.

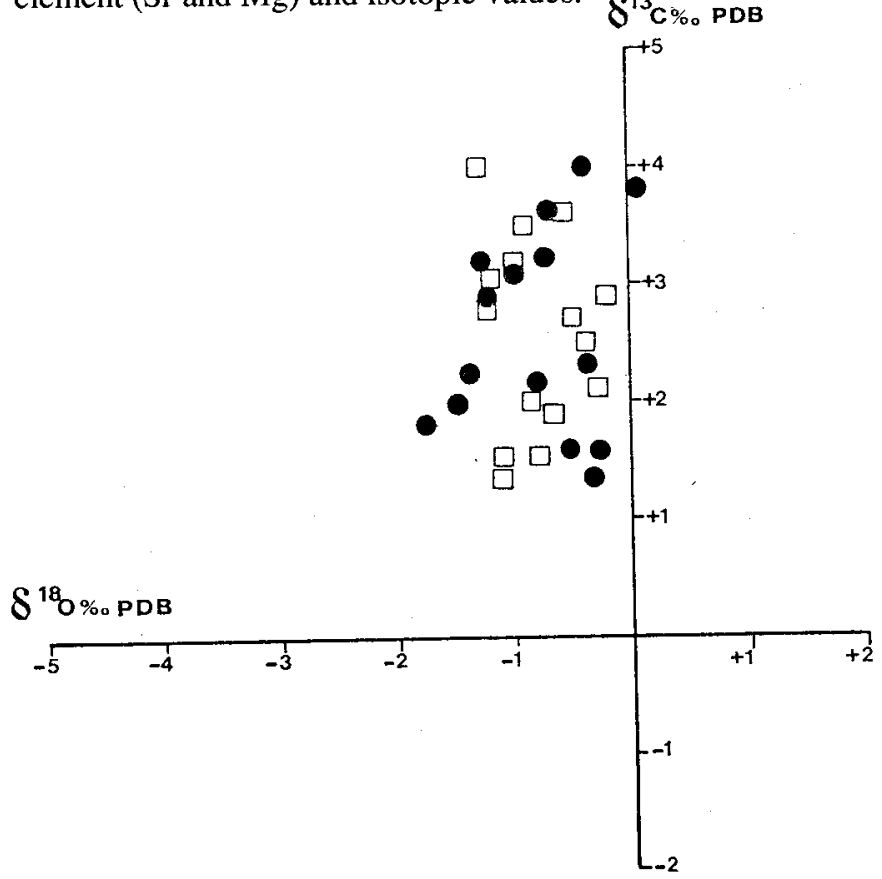

Fig. 5: Cross plot of $\delta^{13} \mathrm{C}$ vs. $\delta^{18} \mathrm{O}$ (PDB) values of marine bivalve shells from the Mediterranean coast of Egypt. Solid circles represent Carditacea and open squares represents Solenacea. 


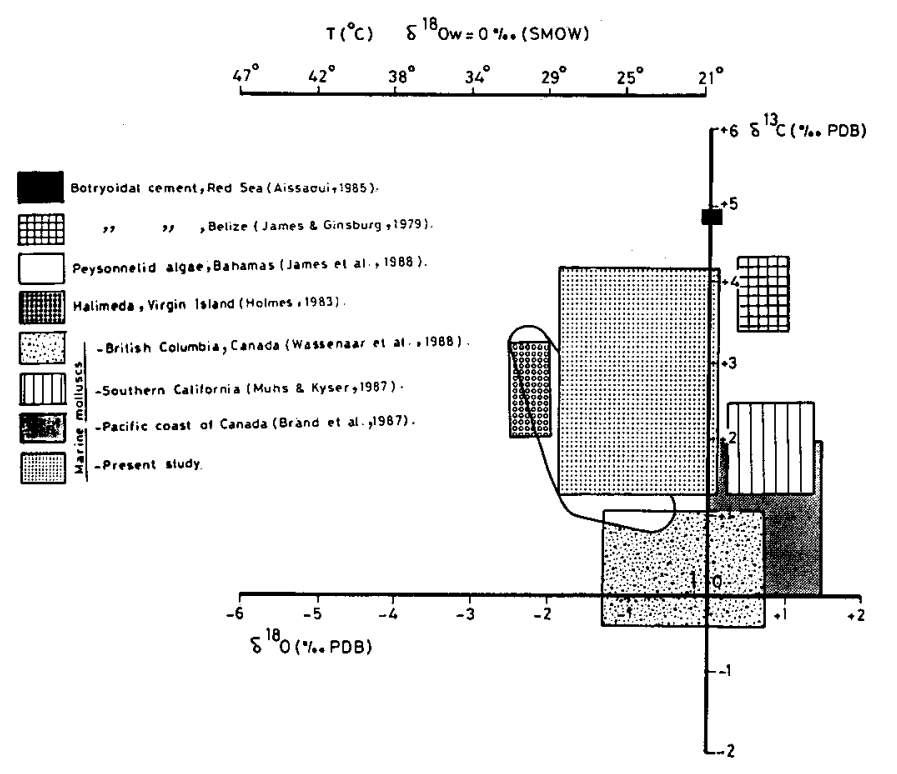

Fig. 6: Comparison of the stable isotopic composition of bivalve shells from this study and relevant comparable materials from various settings. Equilibrium temperature relationship for aragonite precipitated from water with $\delta^{18} \mathrm{O}=0 \% \mathrm{SMOW}$, top of figure (Grossman and $\mathrm{Ku}, 1986$ ).

Most bivalves precipitate their shells in isotopic equilibrium with the ambient seawater (Lowenstam, 1971; Brand and Veizer, 1981). In bivalve, the normal range of $\delta^{13} \mathrm{C}$ is from -2.0 to $+2.0 \%$ PDB and the normal range of $\delta^{180}$ is from -4.0 to $+3.0 \%$ PDB (Morrison and Brand, 1986). The $\delta^{13} \mathrm{C}$ of the studied bivalve shells have a large spread of carbon values ranging from +1.4 to $+4.0 \%$ PDB, and averaging $+2.5 \%$ PDB (Fig. 5). These values are fall mainly within the range of carbonate precipitated in isotopic equilibrium with their ambient seawater. The $\delta^{13} \mathrm{C}$ values of the studied bivalve shells are in the same compositional range as botryoidal marine aragonite cements (Aissaoui, 1985). This range is enriched in $\delta^{13} \mathrm{C}$ relative to the most marine molluses (Fig. 6). The $\delta^{13} \mathrm{C}$ values of the bivalve shells can vary according to salinity range of the seawater. Meanwhile, the $\delta^{13} \mathrm{C}$ is relatively insensitive to temperature changes (approx. $-0.035 \%$ per ${ }^{\circ} \mathrm{C}$ ) compared with oxygen isotopes, and therefore ${ }^{13} \mathrm{C}$ can be used successfully to monitor total dissolved carbon in solutions from which carbonate is precipitated (Arthur et al., 1983). The enriched ${ }^{13} \mathrm{C}$ values of the studied bivalve shells suggest that no terrestrial organic carbon was present and that isotopic carbon was most likely derived largely from inorganic marine carbonate reservoirs.

Oxygen isotopes of all studied shells have roughly similar 180 values between -1.8 and $+0.1 \%$ PDB (Fig. 5). These values are similar to those of the recent molluscs from the Late Quaternary of southwestern British Columbia and the Peysonnelid algae from Bahamas (Fig. 6). On the other hand, these values are slightly more negative than those of the marine molluscs from southern California and the Pacific coast of Canada and modern botryoidal aragonite cement (Fig. 6). Jones (1985) demonstrated that the oxygen isotopes in bivalve shells can vary according to the salinity range of the seawater, as well as the result of possible seasonal calcification. In this study, since the salinity does not show any significance variations, seasonal temperature changes might explain the observed range of the $\delta^{18} \mathrm{O}$ values.

The environmental study may still be completed by biological fractionation of stable isotopes by invertebrates. In this case, the oxygen isotope data reflect biological conditions of the organism and not conditions of the ambient seawater. However, the $\delta 180$ values of the modern bivalve shells indicate that biological fractionation effects are minimal and $\delta 18 \mathrm{O}$ values are a reliable indicator of temperature of the bodies of water in which they grew (Milliman, 1974). In this study, once the bivalve shells are unaltered and the biological effects are minimal, the chemistry of the studied shells should reflect a record of the physico-chemical conditions of the ambient seawater.

In order to estimate precipitation temperatures from the measured $\delta^{18} \mathrm{O}$ values, it is necessary to know $\delta^{18} \mathrm{O}$ of water in which the aragonitic shells were formed. Therefore, the ambient water temperature can be calculated using Grossman and Ku's equation (1986), assuming present day seawater values of $\mathrm{O}(\mathrm{SMOW})$ :

$$
\mathrm{T}\left({ }^{\circ} \mathrm{C}\right)=20.6-4.34\left(\delta^{18} \mathrm{O}_{\mathrm{A}}-\delta \mathrm{W}\right)
$$

On the assumption that a $1^{\circ} \mathrm{C}$ temperature difference is equivalent to a $\delta^{18} \mathrm{O}$ difference of about $0.23 \%$ (Epstein et al., 1953), the difference in water temperature between the winter and summer in the study area is about $8^{\circ} \mathrm{C}$ on the basis of oxygen isotope data (Fig. 6). These values correspond to a temperature range of 20 to $28^{\circ} \mathrm{C}$, which agrees well with the measured temperature range of the seawater. These data support the hypothesis that the oxygen isotopes are incorporated within the aragonitic bivalve shells in thermal equilibrium. Meanwhile, the calculated temperature changes are in agreement at all sites of the study area and indicates that the bivalve shells formed in warm and shallow marine waters.

\section{CONCLUSIONS}

Mircrostructural, mineralogical and geochemical analyses for Carditacea and Solenacea and their comparison with other published results suggest the following conclusions.

1. The bivalve shells are definitely preserved in their original mineralogy (aragonite) and chemistry and do not show any diagenetic trend.

2. Stable isotope geochemistry reveal a distinct isotopic field in comparison with molluscs, Halimeda, algae and botryoidal aragonite cements from other localities.

3. The bivalve organism precipitated their aragonitic shells in isotopic equilibrium with warm marine waters and the shell isotopic composition varies seasonally by less than $2 \%$ for $\delta^{180}$.

\section{ACKNOWLEDGEMENTS}

The authors would like to thank Dr. K. C. Lohmann (University of Michigan) for the access to the mass-spectrometer and Dr. S. El Beialy (University of Qatar) 
for fruitful discussions. SEM work were carried out in the University of Qatar's TM unit.

\section{REFERENCES}

Aissaoui, D. M., 1985. Botryoidal aragonite and its diagenesis. Sedimentology, 32: 345-361.

Allen, J. A., 1960. Manganese deposition on the shells of living molluscs. Nature, 185: 336-337.

Al-Aasm, I.S. and J. Veizer, 1986. Diagenetic stabilization of aragonite and low-Mg calcite, 1. Trace elements in rudists. J. Sed. Petrology, 56: 138-152.

Arthur, M. A., T. F. Anderson, I. R. Kaplan, J. Veizer and L. S. Land, 1983. Stable isotopes in sedimentary geology SEPM, Short Course, No. 10, p. 435.

Barbin, V., K. Ramseyer, J. P. Debenay., E. Schein, M. Roux and D. Decrouez, 1991. Cathodoluminescence of Recent biogenic carbonates carbonates: an environmental and ontogenetic fingerprint, Geological Mag., 128: 19-26.

Bathurst, R. G., 1975. Carbonate sediments and their diagenesis (2nd edition). Amsterdam, the Netherlands, Elsevier, p. 658.

Brand, U. and J. Veizer, 1980. Chemical diagenesis of a multicomponent carbonate system-2: stable isotopes. J. Sed. Petrology, 51: 987-997.

Brand, U. and J. Veizer, 1983. Origin of coated grains: Trace element constraints, In. T. M. Peryt (ed.), Coated grains. Springer-Verlag, Berlin Heidelberg, pp. 9-26.

Brand, U., J. Morrison, N. Brand and E. Brand, 1987. Isotopic variation in the shells of recent marine invertebrates from the Canadian Pacific coast. Chemical Geology, 65: 137-145.

Craig, H., 1957. Isotopic standards for carbon and oxygen and correction factors for mass spectrometric analyses of carbon dioxide. Geochim. Cosmochim. Acta, 12: 133-149.

Epstein, S., R. Buchsbaum, H. A. Lowenstam and H. C. Urey, 1953. Revised carbonate-water isotopic temperature scale. Bull. Geol. Soc. Am., 64: 1315-1326.

Friedman, G. M., 1968. Geology and geochemistry of reefs, carbonate sediments, and waters. Gulf of Aqaba (Elat), Red Sea. J. Sed. Petrology, 38: 895-919.

Grossman, E. L. and T. L. Ku, 1986. Oxygen and carbon isotope fractionation in biological aragonite. Temperature effects. Chemical Geology, 59: 58-74.

Harris, R. C., 1965. Trace element distribution in molluscan skeletal material. Bulletin of Marine Science, 15: 265-273.

Holail, H. and M. Rashed, 1992. Stable isotopic composition of carbonate-cemented recent beachrock along the Mediterranean and the Red Sea coasts of Egypt. Marine Geology, 106: 141-148.
James, N. P. and R. N. Ginsburg, 1979. The seaward margin of Belize Barrier and Atoll Reefs. Int. Assoc. Sedimentol. Spec. Publ. No. 3, p. 191.

James, N. P., J. L. Wary and R. N. Ginsburg, 1988. Calcification of encrusting aragonite algae (Peyssonneliaceae). Implications for the origin of late Paleozoic reefs and cements. J. Sed. Petrology, 58: 291-303.

Jones, D.S., 1985. Growth increments and geochemical variations in the mulluscan shell. In T. W. Broadhead (ed.), Mollusks. University of Tennessee, Knoxville, Tenn., Stud. Geol., 13: 72-87.

Kinsman, D. J., 1969. Interpretation of $\mathrm{Sr}^{2+}$ concentrations in carbonate minerals and rocks. Sed. Petrology, 39: 486-508.

Kinsman, D. J. and H. D. Holland, 1969. The co-operation of cations with $\mathrm{CaCO}_{3}$.IV. The coprecipitation of $\mathrm{Sr}^{2+}$ with aragonite between 16 and $96^{\circ} \mathrm{C}$. Geochem. Cosmochim. Acta, 33: 1-17.

Lowenstam, H. A., 1961. Mineralogy, $18 \mathrm{O} / 16 \mathrm{O}$ ratios, and strontium and magnesium contents of Recent and fossil brachiopods and their bearing on the history of the ocean. J. Geology, 69: 241-260.

Lowenstam, H. A., 1963. Biologic problems relating to the composition and diagenesis of sediments. In $T . W$. Donnelly (ed.), The earth Sciences - Problems and Progress in Current Research. Univ. Chicago Press, Chicago, III, pp. 137-195.

Milliman, J. D., 1974. Marine carbonate. Berlin, Springer-Verlag, p. 375.

Morrison, J. O. and U. Brand, 1986. Geochemistry of recent marine invertebrates. Geoscience Canada, 13: 237-254.

Muhs, D. R. and T. K. Kyser, 1987. Stable isotope compositions of fossil mollusks from southern California: Evidence for a cool last interglacial ocean. Geology, 15: 119-122.

Rye, D. M. and M. A. Sommer, 1980. Reconstructing paleotemperature and paleosalinity regimes with oxygen isotopes. In: D. C. Rhoads and R. A. Lutz (eds.), Skeletal growth of aquatic organisms. Plenum, New York, N.Y., pp. 169-202.

Veizer, J., 1983. Chemical diagenesis of carbonates; theory and application of the trace element technique. In Stable isotopes in sedimentary geology, SEPM Short Course, Notes no. 10, 3, 1-100.

Wassenar, L. I., U. Brand and J. Terasmae, 1988. Isotopic and elemental geochemistry of marine invertebrates from the Late Quaternary Fort Langley Formation and Capilano sediments, southwestern British Columbia, Canada. Chemical Geology, 73: 221-231. 